\title{
Initial Upper Paleolithic bladelet production: Bladelets in Moravian Bohunician
}

\author{
Produkce čepelek v iniciálním mladém paleolitu: \\ čepelky v moravském bohunicienu
}

- Yuri E. Demidenko*, Petr Škrdla, Tereza Rychtaříková -

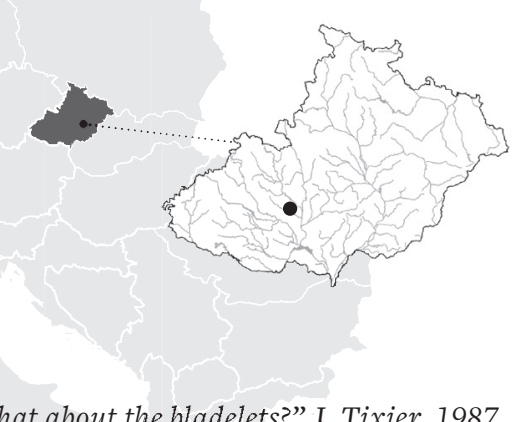

“What about the bladelets?" I. Tixier, 1987

(Williams, Bergman 2010, 117)

\section{KEYWORDS:}

Initial Upper Palaeolithic - Bohunician - bladelets - Boker Tachtit Kara-Bom - Ořechov

\section{ABSTRACT}

Bladelets are a common Upper Palaeolithic technological category, often described as a proxy for the Early Upper Palaeolithic. However, bladelet production has already been documented within preceding Initial Upper Palaeolithic techno-complexes, e.g. at Boker Tachtit (Negev Desert, Israel) and Kara-Bom (Altai Republic, Russian Federation). Only isolated bladelets have been reported from the Central European Bohunician. However, a recently discovered and excavated site, Ořechov IV - Kabáty has yielded a large series (over 1,000 items) of micro-blades and bladelets, documenting a higher degree of technological heterogeneity of the Bohunician techno-complex than previously thought.

\footnotetext{
* Corresponding author - E-mail address: yu.e.demidenko@gmail.com

\section{Introduction}

The "bladelet issue" continues to be central to continuing discussions on the recognition of various Early Upper Palaeolithic (UP) techno-complexes and industry types in the Levant, especially concerning the identification of the so-called true $\mathrm{Au}^{-}$ rignacian in the region (for the latest discussions, see Williams, Bergman 2010; Demidenko, Hauck 2017; Goring-Morris, Belfer-Cohen 2018). The present paper touches on the bladelet issue for the chronologically earlier Initial UP techno-complexes in Eurasia (Fig. 1) and particularly its Central European Bohunician "representative".

Nowadays it can be surely said that the bladelet issue is indeed one of the most discussed subjects in Eurasian Palaeolithic Archaeology (e.g. Le Brun-Ricalens et al. eds. 2005). From our point of view, this is mostly due to the recognition of the important role of bladelets in the hunting projectile weaponry of UP humans. The appeal of the issue has also resulted in some special bladelet studies with respect even to the Middle Palaeolithic (e.g. Slimak, Lucas 2005), although even if recent in-depth studies have confirmed purposeful bladelet primary production as early as the Early Middle Palaeolithic, they have not demonstrated their use as inserted components of any projectile weapons in that period (Wojtczak et al. 2014). Studies of Bohunician in Moravia, in the heart of Central Europe, carried out by one of the authors, Petr Škrdla, have been undertaken over the past 20 years and recently brought to light some previously unknown bladelet data for the very beginning of the UP in Central Europe

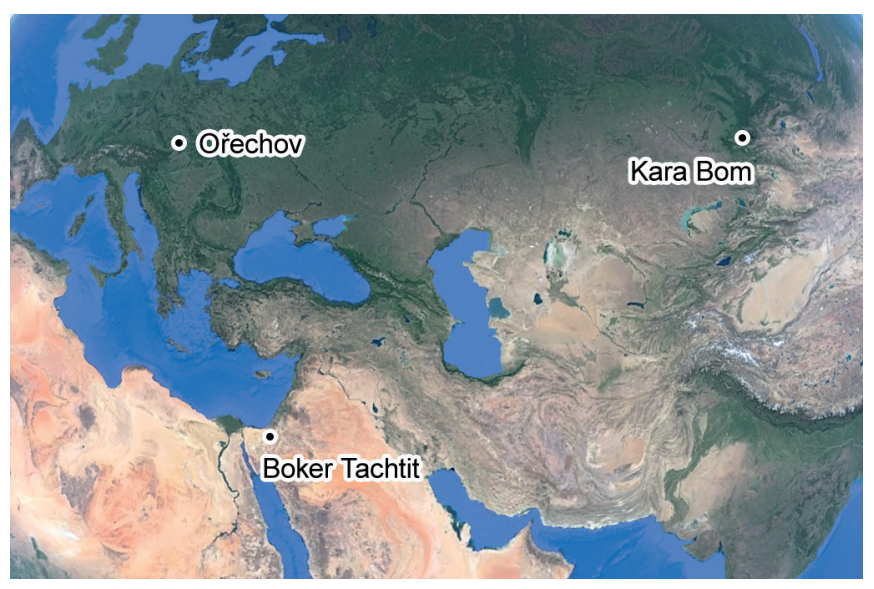

Fig. 1. Map of key sites mentioned in the text. Ořechov, Boker Tachtit and Kara-Bom. Image Landsat/Copernicus, Google Earth.

Obr. 1. Mapa s klíčovými lokalitami zmíněnými v textu. Ořechov, Boker Tachtit a Kara-Bom. Zdroj: Landsat/Copernicus, Google Earth. 
(Škrdla 2017; Škrdla et al. 2017). Accordingly, a need has emerged for an analysis of the issue of Bohunician bladelets. This will be the focus of the present article, which will also discuss the entire Initial UP in Eurasia. Another reason why it is especially interesting to study the "bladelet issue" and the possible use of bladelets for the Initial UP is the chronological position of the techno-complex in question, being between Middle Palaeolithic assemblages with bladelets having no hunting projectile function and Early UP ones with "hunting projectile bladelets".

\section{Ořechov IV - Kabáty}

The site Ořechov IV - Kabáty is located $7.5 \mathrm{~km}$ to the southwest of Bohunice type-site and $14 \mathrm{~km}$ to the southwest from the Stránská skála raw material outcrop. Systematic excavation of a shallow depression filled with intact sediments containing in situ artefacts, located within the artefact cluster on the surface of Ořechov IV, was carried out during Spring and Summer 2017 (Škrdla 2017). The excavation encompassed a total area of $25 \mathrm{~m}^{2}$ and produced a collection of 30,000 artefacts. Eighty percent of the artefacts are made from Stránská skála-type chert, followed by Krumlovský les-type chert (8\%), other local raw materials (3\%), and unspecified burnt rocks. Technologically, the collection is characterised by numerous products of the Levallois technology. A very unique feature of this assemblage is unretouched microblades, bladelets, and their fragments (all together over 1,000 items) (Way et al. 2020). The distribution of their widths fits with a Gaussian distribution with a mean around $7.2 \mathrm{~mm}$ (Fig. 2). Many of them have a facetted striking platform and several items can be classified as "miniaturised Levallois points". The prevailing tool types are Levallois points followed by simple flat and thin end-scrapers with non-lamellar removal negatives. The retouched tool spectrum is completed by lightly retouched blades and their fragments, truncated artefacts, a point tip, and a burin. Two available dates (from hearth $\mathrm{H} 6$ and a pit on its periphery) range from 41 to $35 \mathrm{cal}$. BP $(39,960 \pm 769 \mathrm{cal}$. BP - Poz91471 and $35,586 \pm 419$ cal. BP - Poz-91470) without a probability

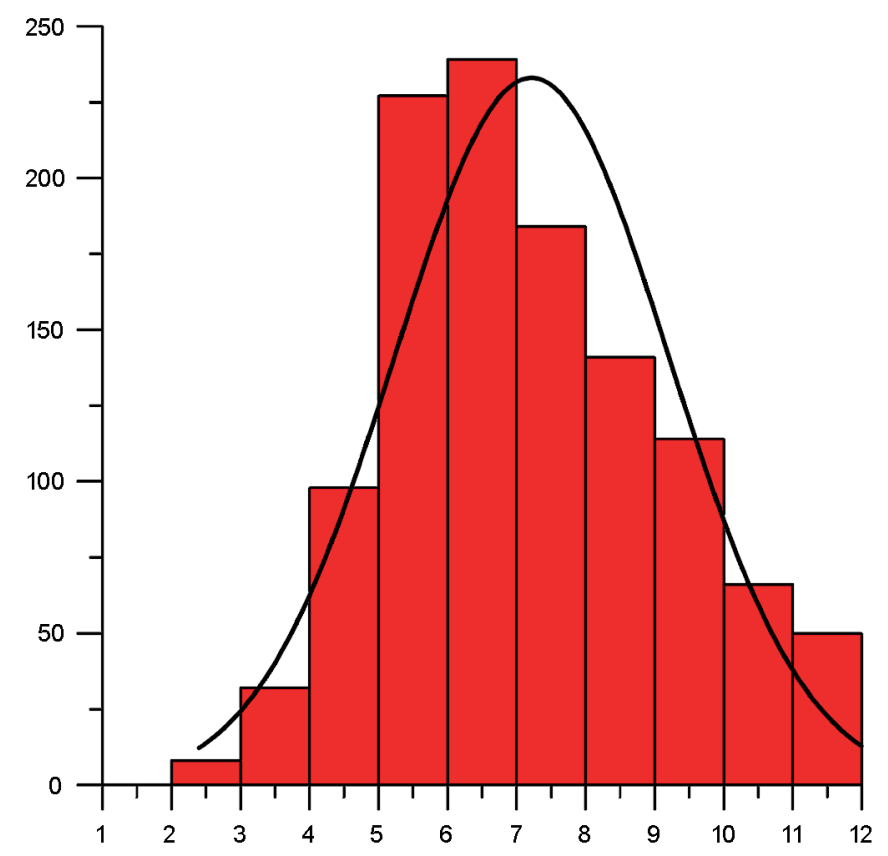

Fig. 2. Histogram of the Ořechov IV bladelet widths. Created by P. Škrdla. Obr. 2. Histogram šířek čepelek z Ořechova IV. Zpracoval P. Škrdla. overlap and both of them are probably underestimated due to contamination (as the samples were collected very close to the topsoil). The south-eastern vicinity of the excavated area is promising for future test pits.

\section{Bladelets in the initial UP of central Asia}

The "bladelet issue" is indeed a very new subject in Initial UP studies. It was actually first seriously touched upon in the context of materials originating from a site situated very far from the Levant where the notion of Initial UP had been originally recognised, studied, and the name coined (see Kuhn et al. 1999; Kuhn 2003; Kuhn, Zwyns 2014), namely the Kara-Bom open-air site in Altai, southern Siberia (Russia). The integrated research on the "bladelet issue" at Kara-Bom was initiated by N. Zwyns during his Altai Initial UP and Early UP PhD studies at the Max Planck Institute for Evolutionary Anthropology, Leipzig, Germany, and was developed by him in collaboration with E. P. Rybin from the Institute of Archaeology and Ethnography of the RAS, Novosibirsk, Russia (see Zwyns 2012; Zwyns et al. 2012). Zwyns, again together with Rybin, and other Russian colleagues from Novosibirsk continued the research concerning systematic bladelet reduction for some other Altai Initial UP sites and made further important observations based on new refit data, concerning bladelet reduction at Kara-Bom and at Initial UP sites in Northern Mongolia (e.g. Derevianko et al. 2013; Zwyns et al. 2014; Slavinsky et al. 2016). Briefly, the bladelet reduction for Initial UP in Central Asia can be summarised as follows.

Bladelets as such do occur in almost every Asian Initial UP assemblage but, from the morphological point of view, they are not very standardised. There are very few rather irregular bladelets with retouch, and again no consistent types and locations of retouch are noted (Zwyns et al. 2012, Fig. 12: 4, 10, 14-15) (Fig. 3). The bladelets correspond well to the flaking objects from which they were detached. From the traditional typological point of view, the vast majority of the bladelet flaking objects are burins and items that resemble burins. From the technological point of view, however, these burins are actually bladelet narrow-flaked cores on debitage pieces, so they can reasonably be termed "burin-cores" (Zwyns et al. 2012, Fig. 9: 4-7, 9). Their blanks were mostly thick, large-sized blades and some elongated flakes, which is why burin-cores are usually considered as having been prepared on blade-blanks. Bladelet reduction was done following long axes of burin-cores either in a bidirectional manner or using one edge after other alternately as striking platforms. As a result, burin-cores often demonstrate "multiple burin-like reductions". Their striking platforms are mainly plain, formed either by simple snapping (typologically, then such a piece looks like an angle burin on a break/snap) or narrow transversal removal (typologically, making such a piece a dihedral angle burin). Not many burin-cores have facetted striking platforms which would make them similar to burins on truncations. As refits demonstrate (Slavinsky et al. 2016, Fig. 5: 5-8), only some of the burin-cores really produced a series of successful (not hinged/overpassed or fragmented) bladelets, while many of them show a detachment of just a few well-produced bladelets. Thus, the burin-cores are rather opportunistic, short-termed reduction objects for obtaining some bladelets. The burin-cores were also added by a few other flaking objects for producing a few more bladelets, truncated-facetted looking items on thick flakes with a flaking surface on either the dorsal or the ventral surface of a flake-blank (Zwyns et al. 2012, Fig. 11: 5-6). The latter pieces are Middle Palaeolithic-like cores on flakes, but at Kara-Bom they mostly bear elongated bladelet removal negatives, which is why they were also identified as one more - though 

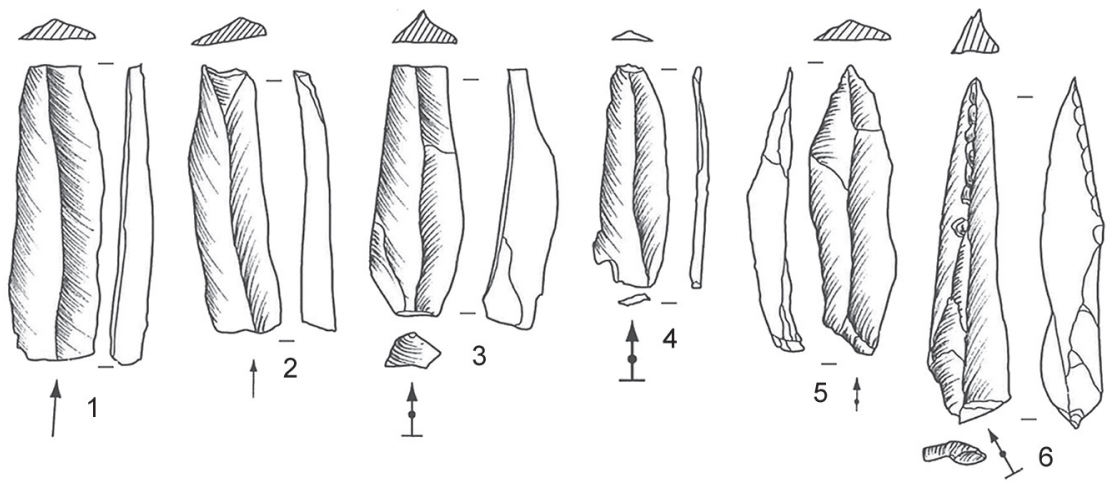

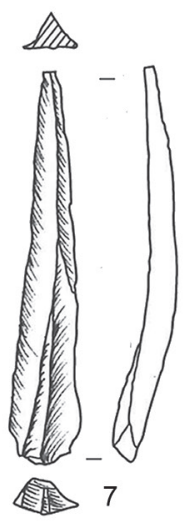

ig. 3. Kara-Bom, OH6. Selected bladelets, a bladelet core, and a point (adapted from Zwyns 2012).

Obr. 3. Kara-Bom, OH6. Vybrané čepelky, jádro na čepelky a hrot (podle Zwyns 2012).

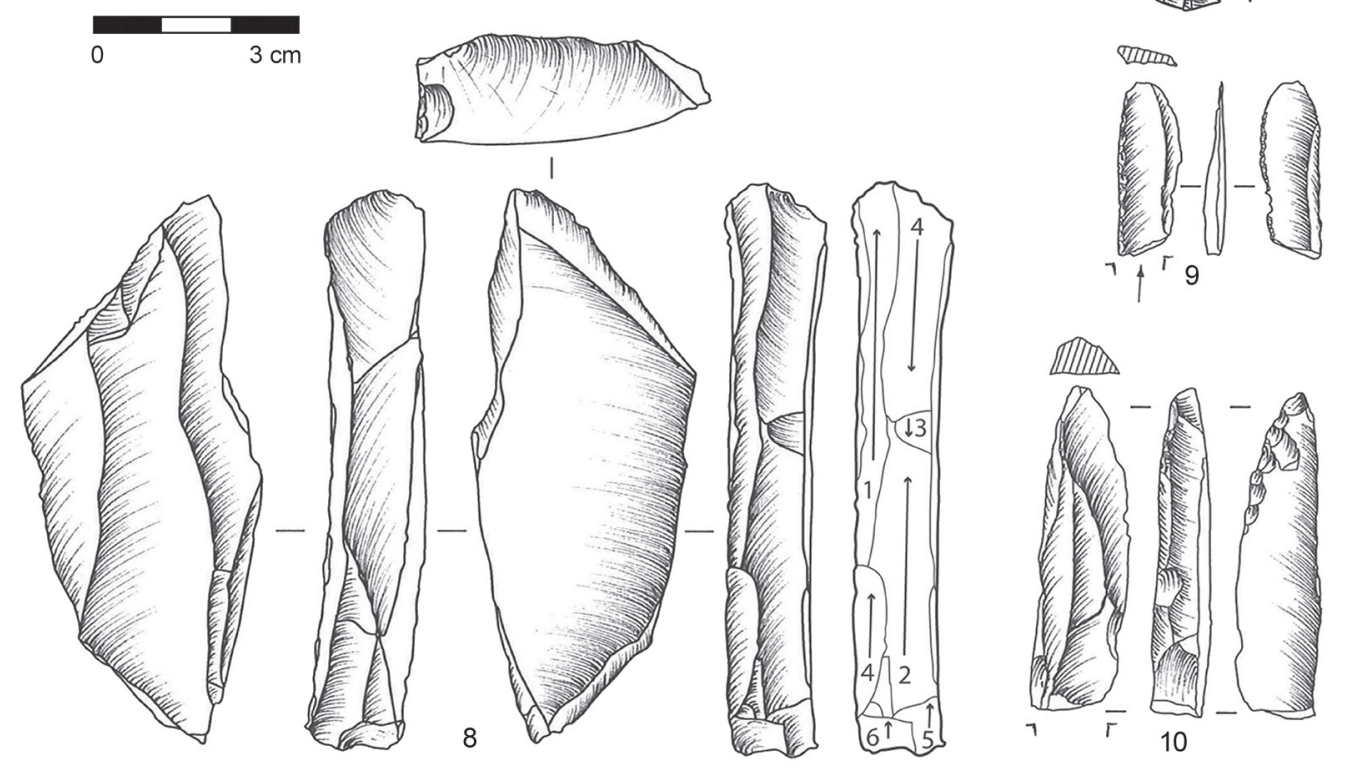

much less important - source of bladelet production. At the same time, no bladelet cores on nodules/chunks have been recognised for the Initial UP in Central Asia, although they are known from Early UP assemblages in the region (Zwyns 2012). From our point of view, the presence of narrow-flaked cores on blades/ burin-cores and flat-faced cores on flakes/truncated-facetted pieces, as well as the absence of bladelet cores on nodules/chunks (which would enable long-lasting systematic bladelet reduction) points towards occasional and still rather non-systematic bladelet reduction. Given the above-mentioned morphologically non-standardised bladelets accompanied by a few randomly retouched pieces, one cannot but conclude that bladelet production in the Initial UP of Central Asia was not systematically planned and carried out. Emphasising once again the very limited number of randomly retouched and morphologically diversified bladelets, it is also clear to us that no bladelets were used as projectiles for hunting in Central Asia during the Initial UP.

\section{Bladelets within other initial UP industries in Eurasia}

The above-described first recognised bladelets of Initial UP, and technologically related specialised flaking objects from Central Asia published in early 2012 (Zwyns et al. 2012) induced one of the authors (Yu. D.) to check the well-published East Mediterranean Levantine Initial UP record for the presence of burin-cores, the most representative indicator of Initial UP bladelet production.

The search for burin-cores has been done in spite of the following note on the Initial UP record in the East Mediterranean Levant and Central Europe at the end of Zwyn's paper on
Kara-Bom burin-cores: "The burin-core technology has not yet been described in assemblages such as Ksar-Akil level XXV-XXI and XXI-XVI, Üçagizli Cave 1, levels G-H, or within Bohunician assemblages" (Zwyns et al. 2012, 45). Such an absence of burin-cores was evident on the basis of recently published data, but there was also a problem with attribution of particular assemblages. While Initial UP sites in Central Asia and their assemblages can be surely connected to the so-called Early Emiran, artefacts from the mentioned levels of Ksar Akil and Üçagizli do belong to the so-called Late Emiran.u. Accordingly, the focus has been put on Early Emiran materials of the Initial UP Levant, and the results are striking. The site of Boker Tachtit (Negev, Israel), typical of Levantine Early Emiran and in particular lithic assemblage from its level 2 (most representative in terms of artefact classes and types), revealed the presence of serial burin-cores on blades (including their refits with detached bladelets done by P. Volkman - Marks, Kaufman 1983, Fig. 5-20a-d), with all their morphological and technological features finding analogies in respective artefacts from Initial UP Central Asia (Marks, Kaufman 1983, Fig. 5-18a, c; 5-19b; 5-21a-b, d) (Fig. 4). Of course, in the early 1980s objects that looked like burins in terms of typology but were used as narrow-flaked cores for bladelets were unknown, thus all these burin-cores were obviously classed just as burins/burin tools. At the same time, it is worth citing here some original notes on burins from Boker Tachtit, level 2, made by the site's excavators and taking into consideration Volkman's refitting data: "... many of the burins were extensively used and modified by a series of spall removal" with "the tendency toward multiple forms" when some burins/burin-cores have "three 

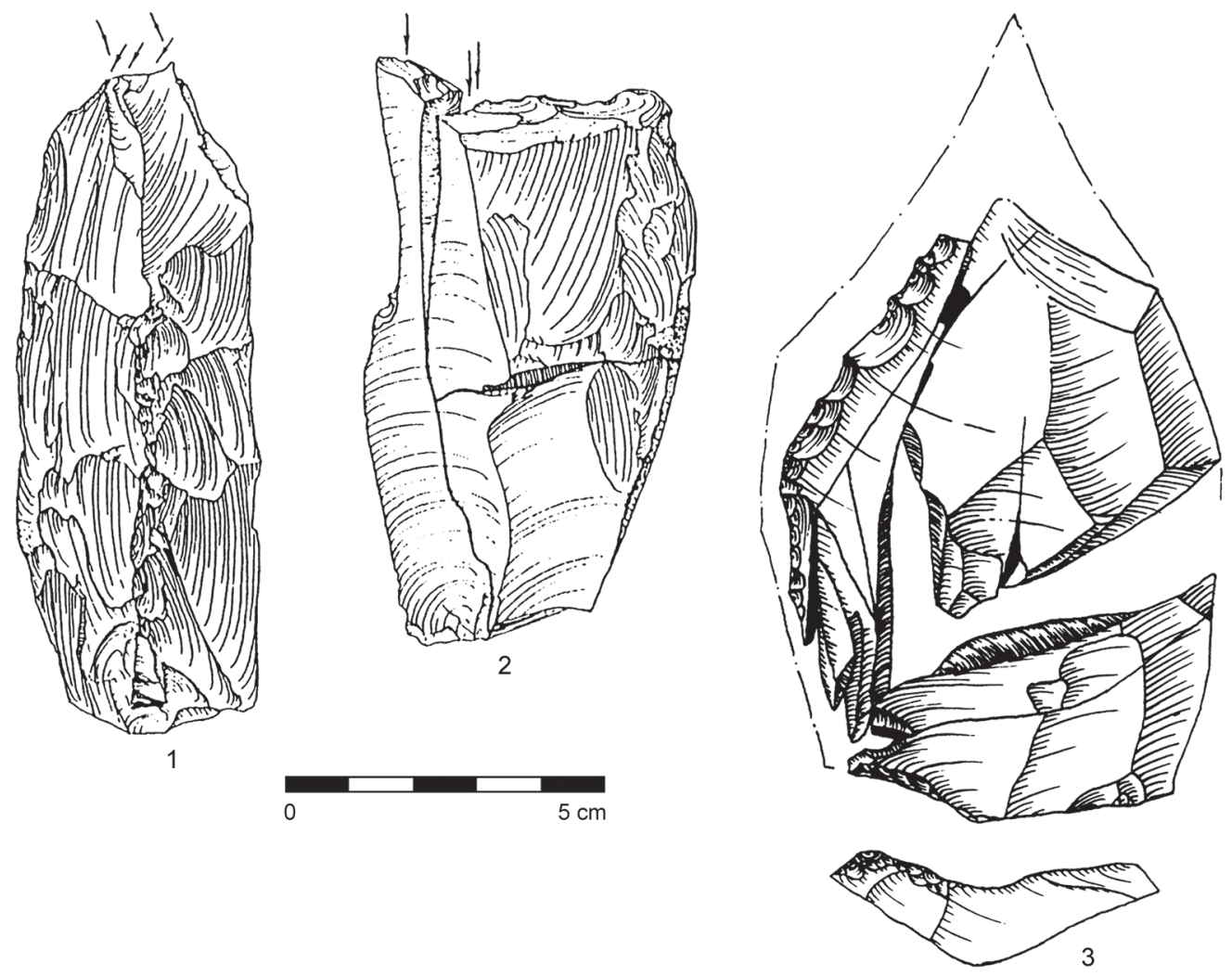

Fig. 4. Boker Tachtit, Level 2. Burins/ burin-cores from the refitted core IAA No. 2001-7 (adapted from Volkman 1983 and Škrdla 2003).

Obr. 4. Boker Tachtit, vrstva 2. Rydla/ rydlová jádra ze složeného jádra IAA No. 2001-7 (podle Volkman 1983 a Škrdla 2003).

burins per piece" showing "the numerous cases of multiple rejuvenations" (Marks, Kaufman 1983, 98). Surely this was just one step from concluding the presence of burin-cores on blades for bladelet production among the Early Emiran materials from Boker Tachtit. This step was taken by Demidenko, first during Zwyns' PhD defence at Leiden University (The Netherlands) in June of 2012 when shortly before the defence the dissertation was published as a book there (Zwyns 2012), and next in Demidenko's first presentation during the "Considering the Initial UP" workshop (MPI, Leipzig, Germany) in December of 2013.The latter presentation was of particular importance as one of the scholars present at the workshop was A. E. Marks, the principal investigator of the Boker Tachtit site in the 1970s and early 1980s; his reaction to the proposition of re-interpreting burins as burin-cores was highly positive. At the same time, it must also be said that no wide-faced cores on flakes/truncated-facetted pieces with serial bladelet removal negatives and retouched microliths have been found at Boker Tachtit, which possibly suggests bladelet production only from burin-cores, with the resulting bladelets used being unretouched, and again not as components of hunting projectile weaponry.

Thus, the Early Emiran at two distant regions of Asia (the Levant and the eastern part of Central Asia) demonstrates the same manner of bladelet production, based on the reduction of burin-cores. Such burin-core co-occurrence in these Initial UP sites located so far away from one another is also worth noting due to some basic differences in their "regular" core reduction technologies. On the one hand, the main purpose in bidirectional core reduction processes in the Levantine Early Emiran were Levallois bidirectional blade points, with the resulting points used (especially retouched) for hafting as either Emireh points having bifacially thinned proximal parts or as simple looking Levallois points but with a special marginal dorsal retouch at the right lateral edge near the butt. On the other hand, Initial UP lithic assemblages in Central Asia lack a proper Levallois bidirectional blade point production system, which is why the proper Levallois points are absent there. These assemblages are, however, characterised by Levallois (sensu lato) bidirectional blade technology based on opposed-platform core reduction with lame à crête technique applied but with no core tablet technique (core striking platform rejuvenation was done through fine faceting), more or less the same as in the Levantine Early Emiran. Accordingly, the main aim of the primary reduction processes was to produce large-sized blades. Some assemblages contain a few pieces that look like Levallois points, but they usually have convergent (not bidirectional!) and multiple scar pattern and/or small facetted butts, which suggests that such pieces were occasionally removed during blade reduction. The assemblages include some terminal points on blades with dorsal and/or ventral retouch, possibly serving for hunting projectile weaponry as proper Levallois points. In light of all these above-described techno-typological data, the Central Asia Initial UP, as well as two other very similar assemblages originating from the Carpathian-Balkan region in Europe (Korolevo II site, layer II in Ukrainian Transcarpathian region and Temnata cave, trench TD-II layer VI in Bulgaria; Gladilin, Demidenko 1989; Usik 1989; Ginter et al. 1996), can be labelled as Early Emiran-like o or non-Levallois point facies of the Early Emiran.

All in all, the wide occurrence of assemblages of Early Emiran/Emiran-like character throughout different regions of Eurasia is striking. One must not forget in this context about Bohunician/Early Emiran in both Central Europe and Eastern Europe (Kulychivka site, lowermost layer III/IV of 1979 and 1984 excavations in western Ukraine; Demidenko, Usik 1993a; Škrdla et al. 2016), which reveal similar and even almost identical techno-typological features. Therefore, it seems reasonable to suggest a dispersal of Initial UP humans (as we think, Homo sapiens) from their "core/origin region" in the East Mediterranean Levant to the above-mentioned regions of Eurasia. As far as we know, such an Initial UP "human dispersal suggestion" was first proposed by J. Svoboda in a conversation with Yu. D. in May of 1993. 
At the same time, Late Emiran with non-Levallois unidirectional volumetric core reduction is so far only known in the Levant and its very local existence does not allow for conclusions about migrations elsewhere into Eurasia, although the Late Emiran later evolved into the Early Ahmarian in the Levant (Marks 1983; Marks, Ferring 1988; for the latest updates, see Goring-Morris, Belfer-Cohen 2018). The most representative Late Emiran assemblages have been found at the following sites: Boker Tachtit, level 4 in Israel; Ksar Akil rock-shelter, Phase I / levels XXV/XXIII-XXI; Antelias cave, layers VII-V; Abu Halka rock-shelter, layers IVf and IVe in Lebanon; Üçagizli cave, layers I-F in the southernmost corner of Turkey; and Umm El Tlel, Paleolithique Intermediare level II in central Syria. Until now, no burin-core bladelet technology has been recognised there. But it might occur there if the recently found and excavated assemblage at Mughr el-Hamamah Cave 2, layer B in Jordan (Stutz et al. 2015; J. J. Shea, personal communication to Yu. D., January 2018), containing both burin-cores and bipolar anvil cores for supplementary primary reduction, really belongs to the Late Emiran. Remarkably, these two technologies also occur in Early Emiran-like assemblages from northern Mongolia (e.g. see the respective illustrations for Tolbor 4, horizons 5-6 in Derevianko et al. 2007).

\section{Bohunician bladelets in central and eastern Europe}

Once again, the Early Emiran/Emiran-like assemblages of Initial UP are often characterised by specialised bladelet reduction. The East European Bohunician at Kulychivka site bears nearly all of the techno-typological features of Moravian Bohunician lithic tradition, including burin-cores (Demidenko, Škrdla - assemblage personal studies, 2015 ). The nearly total absence of bladelets within the Kulychivka lithic collections is also understandable given the gross excavations performed at the site in the 1970s and 1980s. At the same time, not a single bladelet core on a nodule/chunk has been found there. Thus, this is the only Early Emiran site in the whole of Eastern Europe that resembles other known Initial UP sites regarding the production, and probably also the use, of some unretouched bladelets. Moreover, the Kulychivka site in western Ukraine and the Stránská skála site cluster in southern Moravia can be called twin sites due to a number of shared topographical and archaeological characteristics: locations on hilltops with high-quality lithic raw material outcrops, which allowed for great hunting control over the surrounding areas, and abundance of finds in both the Bohunician/Early Emiran and Evolved Aurignacian archaeological layers, while chronologically much later Epigravettian assemblages were scarce (Demidenko 2018, 271). Thus, we are dealing here with more or less twin Initial UP sites in Central and Eastern Europe separated by approximately $800 \mathrm{~km}$ on a straight line, which again allows us to suggest some human movements between the two regions in Central and Eastern Europe during the very beginning of the UP period. There is, however, one main lithic difference between the Bohunician sites, not only Stránská skála, and Kulychivka: namely the apparent absence of truly systematic bladelet production in the Moravian Bohunician - even including the lithic assemblage from Brno-Bohunice-Kejbaly IV site, area A, where systematic wet-sieving of all the cultural sediments during the excavations in 2002 did not yield any serial bladelets (Škrdla 2017, 42-47). Very few bladelets still can be identified in some Bohunician collections.

All in all, it appears that the Ořechov IV - Kabáty Bohunician assemblage, with many bladelets (none of which was retouched) but only a single burin-core and no other primary reduction objects for bladelet production, actually stands out among the other Bohunician assemblages in Moravia. At the same time, it is similar to Emiran/Emiran-like assemblages in both Europe and Asia.

This situation calls for an explanation and so far we propose the following two basic suggestions:

1) Why not consider an evolutionary suggestion, in which the bladelet component would represent a new technological element of the Bohunician lithic system in its development toward other Early UP techno-complexes in Central Europe? There are two techno-complexes that could be industrially viewed for such an evolutionary trend, namely Aurignacian and Lincombian-Ranisian-Jerzmanowician (LRJ). But to suggest it, without even a mention of proof, one would need to demonstrate some real Aurignacian or LRJ techno-typological elements connected to bladelet reduction within the Ořechov IV - Kabáty assemblage and possibly in some other Bohunician lithic collections.

Aurignacian was already suggested for a generic connection with Bohunician (Nejman 2006). Now, however, this should be done at another level of our Moravian Initial and Early UP understanding. First of all, many surface collections in southern Moravia where Bohunician and Aurignacian lithic objects were found together actually represent the mixing of artefacts left at the same spots after separate episodes of Bohunician and then Aurignacian occupation. Second, during the 1980s excavations by J. Svoboda (Svoboda 1987) in the Stránská skála site cluster some sites were found (e.g. Stránská skála IIIa and IIIb) with in situ sequences of archaeological layers having Bohunician lithics for a lower palaeosoil and "Middle Aurignacian" (Evolved Aurignacian sensu Demidenko et al. 2017) lithics for an upper palaeosoil. As lithic analyses have showed, Bohunician layers did contain some "high end-scrapers" that could be fuel for speculation concerning some Aurignacian genuine features in the Bohunician techno-complex. However, at Stránská skála IIIa, the presence of an Aurignacian end-scraper-core in the Bohunician layer on one hand and the occurrence of some Levallois pieces in the Aurignacian layer on the other, was explained by some stratigraphy problems (cryoturbation) resulting in movements of artefacts between the layers (Kozlowski 1988, 219). Accordingly, the in situ Bohunician layers at Stránská skála sites do not contain any genuine Aurignacian lithic types. Third, no carinated pieces with lamellar removal negatives (Aurignacian-like core and/or tool types) occur in the Ořechov IV - Kabáty assemblage. All these data do not allow us as yet to suppose any generic connections between Bohunician and Aurignacian, particularly with respect to the Ořechov IV - Kabáty assemblage.

Looking for possible further development of the Bohunician, LRJ seems a good candidate due to the basic core bidirectional reduction shared by the two techno-complexes and the rather frequent occurrence of LRJ-type-like points in all Initial UP and Early UP assemblages, including the materials from surface collections as well. One of the authors of this paper (Yu. D.) is now seeking concrete grounds for the presence of LRJ sites and their assemblages in Moravia. However, the Ořechov IV - Kabáty lithic collection does not demonstrate any known LRJ techno-typological elements (see Flas 2008). This is why the mere presence of bladelets, which are only suggested (!) to be present in LRJ Early UP industry (Flas 2011, 612), is not enough to speak for an evolutionary trend toward LRJ on the basis of the Ořechov IV - Kabáty materials.

2) Another possible explanation for the great bladelet presence in the Ořechov IV - Kabáty Bohunician assemblage can be linked to the already noted miniaturization of the lithics. This site is the most distant Bohunician site from the Stránská skála chert outcrop (approx. $14 \mathrm{~km}$ in a straight line, and no less than 
$20 \mathrm{~km}$ for any journey on foot through the hilly terrain in Southern Moravia), which is why chert nodules were heavily flaked and reduced during their likely intensive and/or multiple primary reductions. The same can be said about Krumlovsky Les-type chert, whose nearest outcrop is located approx. $7 \mathrm{~km}$ from the site. As a result, it is possible that only a few bladelets were detached from a single burin-core, while the remaining numerous bladelets originate from the reduction of Levallois points. For the latter case it means that small-sized cores were flaked for small Levallois points with blades and some bladelet removal negatives on their dorsal surfaces (Škrdla 2017, Fig. 3.11: 20-27). Before the detachment of a Levallois point the necessary Y-arrete scar pattern had to be formed by elongated removals bearing facetted butts (being more elongated than the resulting
Levallois point), as it is evident from some refitting data (e.g. Demidenko, Usik 1993b; 1994; 2003; Škrdla 2003). In Ořechov IV - Kabáty, the Y-arrete pattern was often shaped through such bladelet detachments. Because of the Orechov IV - Kabáty "miniaturization", the bladelets were actually smallsized blades, and a good series of bladelets with facetted butts is noted here (Škrdla 2017, Figs 3.11: 5, 7-10, 16). It should also not be forgotten that bladelets are small-sized pieces with miniscule butts because hammer blows at the very edges of the striking platform of a core would often deliver bladelets with crushed, linear, and punctiform butts. As a result, the real number of bladelets with facetted butts coming from the reduction of Levallois point cores should be even higher than their actual presence in the assemblage, if we consider that bladelets removed
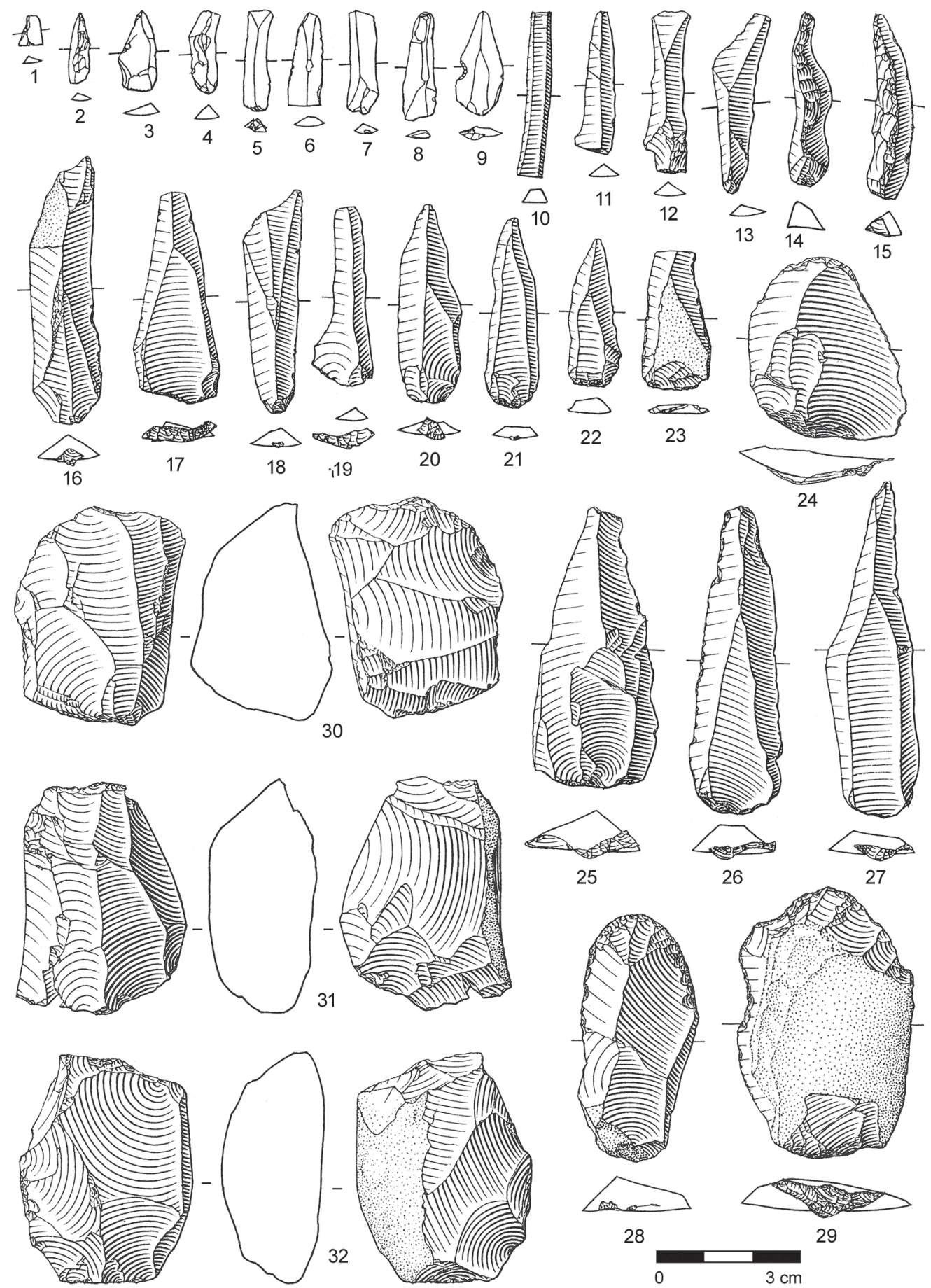

Fig. 5. Ořechov IV. Selected artefacts (adapted from Škrdla 2017).

Obr. 5. Ořechov IV. Vybrané artefakty (podle Škrdla 2017). 
from real bladelet cores (missing at Ořechov IV - Kabáty) have plain/linear/punctiform butts due to the plain striking platforms of the cores. Also, all of the complete Levallois cores (Škrdla 2017, Fig. 3.10: 15, 19-20) are no longer than $5 \mathrm{~cm}$. Accordingly, metric proportions typical of bladelets can be surely suggested for many elongated debitage pieces shaping/re-shaping core flaking surfaces, and even for some Levallois points.

Support for such a hypothesis about the great intensity and multiple character of Levallois bidirectional point reduction at the discussed Ořechov IV - Kabáty site can be found in materials of the Early Emiran type from Boker Tachtit where at least one case is known from level 1, where both a small-sized Levallois point core and the point itself are present (Marks, Kaufman 1983, Fig. 5-2b) and where the core bears some bladelet-sized preparatory elongated removal negatives. This is for certain an intensity reduction factor for the site where Initial UP humans were literally sitting on the high-quality chert outcrop. The occurrence of bladelets made on Krumlovský Les chert (the straight distance to its outcrops is approx. $7 \mathrm{~km}$ from the site) at Ořechov IV - Kabáty could be also explained by an intensive primary flaking of chert nodules brought to the site from relatively distant outcrops, remembering that this particular chert type is characteristic of two well-known Moravian Early Szeletian EUP sites, namely Vedrovice V and Moravský Krumlov IV, layer 0 , situated right at the chert outcrops. As a result, the particular Ořechov IV - Kabáty Bohunician assemblage might represent a specific Bohunician Initial UP site where the use of rather distant chert outcrops did "subjectively" lead to the assemblage miniaturization causing its "artificial bladelet character" (Fig. 5). This explanation is highly probable given the location of virtually all of the known Eurasian Initial UP sites: at or very close to high-quality raw material outcrops.

Summing up the above-represented hypotheses and discussions, we are inclined to accept the last one. Accordingly, it can be said that the Central European variant of Early Emiran, Bohunician, does not actually demonstrate proper independent bladelet production, in contrast to many other known Early Emiran assemblages in Eurasia. And the great bladelet presence at Ořechov IV - Kabáty is only caused by "subjective reasons" stemming from the reduction of some Levallois bidirectional points.

\section{Possible use of early Emiran/Emiran-like initial UP bladelets}

Taking into consideration the exclusively burin-core technology with no thick bladelet cores on nodules/chunks used in bladelet primary production, and the fact that the resulting bladelets were not retouched, it appears that the bladelet production was to a high degree a supplementary reduction method for Initial UP humans. Such Initial UP bladelet production and use is similar to that of an Early MP example recently studied by one of us (Yu. D.) (Wojtczak et al. 2014). That is Hummalian industry in the Levant, characterised by similar burin-cores and even with a very few real bladelet volumetric cores (but on thick debitage pieces rather than on nodules/chunks), where the detached bladelets were not retouched either. Using all the basic comparative and some particular Hummalian use-wear data, it was suggested that the Hummalian unretouched bladelets served as small-sized butchering tools. At the same time, it is worth noting that Hummalian wide-faced cores on flakes/truncated-facetted pieces are core-like objects for small-sized flake and chip detachment, while the Initial UP wide-faced cores on flakes/truncated-facetted pieces, if they occur like in the Central Asia Initial UP record, were often used for bladelet reduction. Turning to the Initial UP data, where Levallois basally bifacially thinned points of Emiren type, Levallois points with special lateral retouch near a butt, and terminally and/or basally retouched blades were probably all used as hunting projectile weaponry, the Initial UP unretouched bladelets were, most likely, a sort of cutting tool as well.

It was only later, post-Initial UP, techno-complexes and their industry types (e.g. Early Ahmarian in the East Mediterranean Levant and Chatelperronian in Western Europe, as well as Pan-Western Eurasian Aurignacian) that the first use of bows/ darts with inserted non-backed retouched bladelets is confirmed for hunting purposes in Eurasia, which shows us that not "all typical UP lithic packages and use habits" were already characteristic for the Initial UP techno-complex and its regionally various industry types. Additionally, there are some evident developmental trends from Initial UP to first Early UP techno-complexes, as it is already well-established for the "evolutionary chain" in the East Mediterranean Levant: Early Emiran of Initial UP Late Emiran of Initial UP - Early Ahmarian of Early UP, and bladelets started to be used in hunting projectile weaponry only during the Early Ahmarian.

\section{Concluding considerations}

The recent discovery of Moravian Bohunician bladelet technology indicates that bladelet production was a common technological skill within Initial UP assemblages all over Eurasia for several millennia preceding the Early Upper Palaeolithic techno-complexes such as Early Ahmarian, Protoaurignacian, and Early Aurignacian. Contrary to the Bohunice and Stránská skála assemblages, the Ořechov IV - Kabáty (Fig. 6) assemblage was preliminarily classified as Developed (from a technological point of view) or Upper (from a chronological point of view) Bohunician. We can conclude that the Moravian Bohunician is not as homogeneous as previously thought and bladelets from the Ořechov IV - Kabáty assemblage fit well technologically with other Initial UP sites including Boker Tachtit and Kara-Bom. However, the Ořechov IV - Kabáty assemblage requires more studies in the near future, including precise dating, refitting, and chaîne opératoire reconstruction.

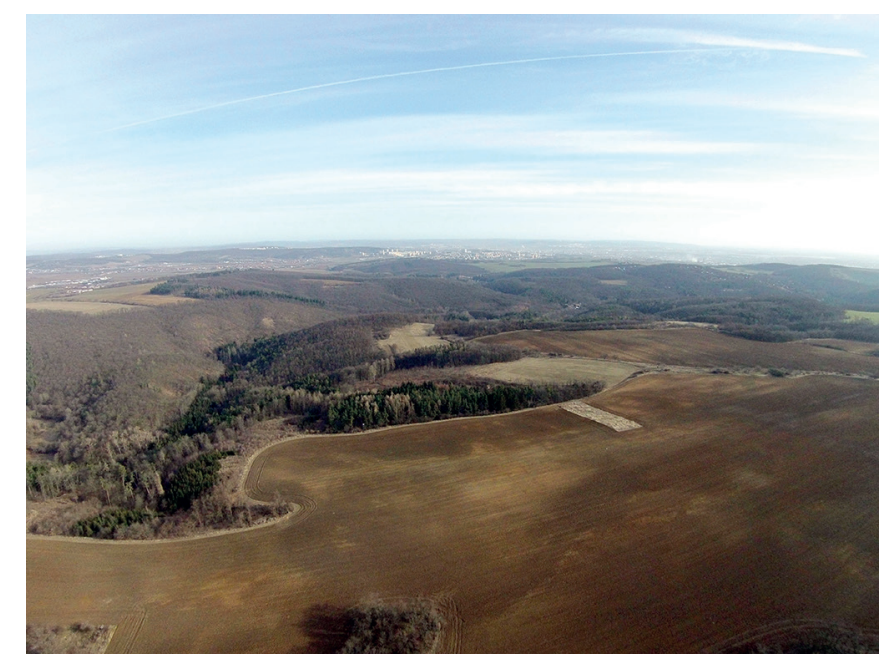

Fig. 6. Ořechov IV. Looking east towards the Bobrava River Valley and Brno Basin. Photo by M. Vlach.

Obr. 6. Ořechov IV. Pohled východním směrem do údolí Bobravy a Brněnské kotliny. Foto M. Vlach. 


\section{Acknowledgements}

The Ořechov IV - Kabáty site was discovered during surveys supported by the Grant Agency of the Academy of Sciences of the Czech Republic, project No. IAA800010801, and the subsequent excavation was funded by the Czech Science Foundation, project No. GA15-19170S. Authors Škrdla and Rychtaříková were supported with institucional support RVO: 68081758 - Czech Academy of Sciences, Institute of Archaeology, Brno. We are grateful to Arina M. Khatsenovich (Novosibirsk, Russia) for supplementing our Initial UP bladelet study with some publications on the related Siberian and Mongolian assemblages.

\section{References}

Demidenko, Yu. E. 2018: Gravett Bol'shogo Severnogo Prichernomoria v kontekste verkhnego paleolita Vostochnoi Evropy / Gravettian in the Great North Black Sea Region in the Context of East European Upper Palaeolithic. Stratum plus 2008(1), 265-283.

Demidenko, Yu. E., Hauck, Th. C. 2017: Yabrud II rock-shelter archaeological sequence (Syria) and possible Proto-Aurignacian origin in the Levant. In: D. Wojtczak, M. Al Najjar, R. Jagher, H. Elsuede, F. Wegmüller, M. Otte (eds.): Vocation Préhistoire. Hommage à Jean-Marie Le Tensorer. Etudes et Recherches archéologiques de l'Université de Liège 148. Liège: Université de Liège, Service de Préhistoire, 87-98.

Demidenko, Y. E., Škrdla, P., Nejman, L. 2017: Aurignacian in Moravia. New geochronological, lithic and settlement data. Památky archeologické CVIII, 5-38.

Demidenko, Yu. E., Usik, V. I. 1993a: On the Levallois technique in the Upper Palaeolithic. In: J. Pavúk (ed.): Actes du XIIe Congrès International des Sciences Préhistoriques et Protohistoriques: Bratislava, 1-7 septembre 1991. Nitra: Archaeological Institute of the Slovak Academy of Science, 239-242.

Demidenko, Yu. E., Usik, V. I. 1993b: The problem of changes in Levallois technique during the technological transition from the Middle to Upper Palaeolithic. Paléorient 19(2), 5-15.

Demidenko, Yu. E., Usik, V. I. 1994: O Levalluazkoi ostriinoi tekhnologii v srednem paleolite (po materialam stoianki Korolevo-1 kompleks 2-V v Ukrainskom Zakarpat'e) / On the Levallois point technology in the Middle Paleolithic (on the materials of Korolevo I site - complex 2b in Ukrainian Transcarpathians). Archeologicheskii al'manakh / Archaeological Almanac 3, 35-46.

Demidenko, Yu. E., Usik, V. I. 2003: Into the mind of the maker. Refitting study and technological considerations. In: D. O. Henry (ed.): Neanderthals in Levant. Behavioral Organization and the Beginnings of Human Modernity. London: Continuum, 107-155.

Derevianko, A. P., Rybin, E. P., Gladyshev, S. A., Gunchinsuren, B., Tsybankov, A. A., Olsen, J. W. 2013: Early Upper Paleolithic stone tool technologies of Northern Mongolia: the case of Tolbor-4 and Tolbor-15. Archaeology, Ethnology and Anthropology of Eurasia, 41(4), 21-37.

Derevianko, A. P., Zenin, A. N., Rybin, E. P., Gladyshev, S. A., Tsybankov, A. A., Olsen, J. W., Tseveendorj, D., Gunchinsuren, B. 2007: The technology of early Upper Paleolithic lithic reduction in Northern Mongolia: The Tolbor-4 site. Archaeology, Ethnology and Anthropology of Eurasia 29(1), 16-38.

Flas, D. 2008: La transition du Paélolithique moyen au supérieur dans la plaine septentrionale de l'Europe. Anthropologica et Praehistorica 119. Bruxelles: Société royale belge d'Anthropologie et de Préhistoire.

Flas, D. 2011: The Middle to Upper Paleolithic transition in Northern Europe: the Lincombian-Ranisian-Jerzmanowician and the issue of acculturation of the last Neanderthals. World Archaeology 43(4), 605-627.
Ginter, B., Kozłowski, J. K., Laville, H., Sirakov, N.,

Hedges, R. E. M. 1996: Transition in the Balkans: news from the Temnata Cave, Bulgaria. In: E. Carbonell, M. Vaquero (eds.): The Last Neanderthals, the First Anatomically Modern Humans. Cultural Change and Human Evolution: The Crisis at $40 \mathrm{ka}$ BP. Tarragona: Universitat Rovira i Virgili, 169-200.

Gladilin, V. N., Demidenko, Yu. E. 1989: Upper Palaeolithic stone tool complexes from Korolevo. Anthropologie XXII(2-3), 143-178.

Goring-Morris, N., Belfer-Cohen, A. 2018: The Ahmarian in the context of the Earlier Upper Palaeolithic in the Near East. In: Y. Nishiaki, T. Akazawa (eds.): The Middle and Upper Paleolithic Archeology of the Levant and Beyond. Replacement of Neanderthals by Modern Humans Series. Singapore: Springer Nature, 87-104.

Kozłowski, J. K. 1988: Transition from the Middle to the Early Upper Paleolithic in Central Europe and the Balkans. In: J. F. Hoffecker, C. A. Wolf (eds.): The Early Upper Paleolithic: Evidence from Europe and the Near East. British Archaeological Reports International Series 437. Oxford: BAR Publishing, 193-235.

Kuhn, S. 2003: In what sense is the Levantine initial Upper Paleolithic a "transitional" industry? In: J. Zilhão, F. d'Errico (eds.): The Chronology of the Aurignacian and of the Transitional Technocomplexes: Dating, Stratigraphies, Cultural Implications. Trabalhos de Arqueologia 33. Lisboa: Instituto Português de Arqueologia, 61-70.

Kuhn, S., Stiner, M., Güleç, E. 1999: Initial Upper Paleolithic in south-central Turkey and its regional context: a preliminary report. Antiquity 73(281), 505-517.

Kuhn, S. L., Zwyns, N. 2014: Rethinking the Initial Upper Paleolithic. Quaternary International 347, 29-38.

Le Brun-Ricalens, F., Bordes, J.-G., Bon, F. (eds.) 2005: Productions lamellaires attribuées à l'Aurignacien: chaînes opératoires et perspectives technoculturelles. Archéologiques 1. Luxembourg: Musée National d'Histoire et d'Art.

Marks, A. E. 1983: The Middle to Upper Paleolithic Transition in the Levant. In: F. Wendorf, A. E. Close (eds.): Advances in World Archaeology 2. New York: Academic Press, 51-92.

Marks, A. E., Ferring, C. R. 1988: The Early Upper Paleolithic of the Levant. In: J. F. Hoffecker, C. A. Wolf (eds.): The Early Upper Paleolithic: Evidence from Europe and the Near East. British Archaeological Reports International Series 437. Oxford: BAR Publishing, 43-72.

Marks, A. E., Kaufman, D. 1983: Boker Tachtit: The Artifacts. In: A. E. Marks (ed.): Prehistory and Paleoenvironments in the Central Negev, Israel. The Avdat/Aqev Area, Part 3. Dallas: Southern Methodist University Press, 69-126.

Nejman, L. 2006: Lithic patterning and land-use during the MiddleUpper Palaeolithic transition in Moravia (Czech Republic). Unpublished doctoral dissertation. Stored in: Archive of Australian National University, Acton.

Škrdla, P. 2003: Bohunician Technology: The refitting Approach. In: J. Svoboda, O. Bar-Yosef (eds.): Stránská skála. Origins of the Upper Paleolithic in the Brno Basin, Moravia, Czech Republic. American School of Prehistoric Research Bulletin 47. The Dolní Věstonice Studies 10. Cambridge: Peabody Museum of Archaeology and Ethnology, Harvard University, 119-151.

Škrdla, P. 2017: Moravia at the onset of the Upper Paleolithic. The Dolní Věstonice Studies 23. Brno: Institute of Archaeology of the Czech Academy of Sciences.

Škrdla, P., Sytnyk, O., Koropets'kyi, R. 2016: New observations concerning Kulychivka, Layer 4. Materiali $i$ doslidzheniya $z$ arkheologii Prikarpattya $i$ Volini / Materials and studies on archaeology of Sub-Carpathian and Volhynian area 20, 15-25. 
Škrdla, P., Rychtař́íková, T., Bartík, J., Nejman, L., Novák, J. 2017: Ořechov IV: nová stratifikovaná lokalita bohunicienu mimo brněnskou kotlinu. Archeologické rozhledy LXIX(3), 361-384.

Slavinsky, V. S., Rybin, E. P., Belousova, N. E. 2016: Variation in Middle and Upper Paleolithic reduction technology at Kara-Bom, the Altai mountains: refitting studies. Archaeology, Ethnology and Anthropology of Eurasia 44(1), 39-50.

Slimak, L., Lucas, G. 2005: Le debitage lamellaire, une invention Aurignacienne? In: F. Le Brun-Ricalens, J.-G. Bordes, F. Bon (eds.): Productions lamellaires attribuées à l'Aurignacien: chaînes opératoires et perspectives technoculturelles. Actes du XIVe congrès de l'UISPP, Union internationale des sciences préhistoriques et protohistoriques, Université de Liège, 2-8 septembre 2001, Session 6, paléolithique supérieur, Colloque / Symposium C6.7. Archéologiques 1. Luxembourg: Musée National d'Histoire et d'Art, 75-100.

Stutz, A. J., Shea, J. J., Rech, J. A., Pigati, J. S., Wilson, J., Belmaker, M., Albert, R. M., Arpin, T., Cabanes, D., Clark, J. L., Hartman, G., Hourani, F., White, G. E., Stutz, L. N., 2015: Early Upper Paleolithic chronology in the Levant: new ABOx-SC accelerator mass spectrometry results from the Mughr elHamamah Site, Jordan. Journal of Human Evolution 85, 157-173.

Svoboda, J. 1987: Stránská skála. Bohunický typ v brněnské kotlině. Studie Archeologického ústavu Československé akademie věd v Brně XIV(1). Praha: Academia.

Usik, V. I. 1989: Korolevo - transition from Lower to Upper Palaeolithic according to reconstruction data. Anthropologie XXVII(2-3), 179-212.

Volkman, P. 1983: Boker Tachtit: Core Reconstructions. In: A. E. Marks (ed.): Prehistory and Paleoenvironments in the Central Negev, Israel. Volume 3, TheAvdat/Aqev Area, Part 3. Dallas: Southern Methodist University Press, 127-190.

Way, A. M., Škrdla, P., Nejman, L., Rychtaříková, T. 2020: New Evidence from Ořechov IV (Czech Republic) for the Production of Microblades During the Bohunician. Journal of Paleolithic Archaeology 3, 59-76.

Williams, J. K., Bergman, C. A. 2010: Upper Paleolithic Levels XIII-XVI (A and B) from the 1937-1938 and 1947-1948 Boston College Excavations and the Levantine Aurignacian at Ksar Akil, Lebanon. Paléorient 36(2), 117-161.

Wojtczak, D., Le Tensorer, J.-M., Demidenko, Yu. E. 2014: Hummalian industry (El Kowm, Central Syria): core reduction variability in the Levantine Early Middle Palaeolithic. Quartär 61, 23-48.

Zwyns, N. 2012: Laminar Technology and the Onset of the Upper Paleolithic in the Altai, Siberia. Studies in Human Evolution. Leiden: Leiden University Press.

Zwyns, N., Gladyshev, S. A., Gunchinsuren, B., Bolorbat, T., Flas, D., Tabarev, A. V., Dogandzic, T., Gillam, G. C., Khatsenovich, A. M., Odsuren, D., Purevjal, K.-E., Richards, M., Stewart, J., Talamo, S. 2014: The open-air site of Tolbor 16 (Northern Mongolia): Preliminary results and perspectives. Quaternary International 347, 53-65.

Zwyns, N., Rybin, E. P., Hublin, J.-J., Derevianko, A. P. 2012: Burincore technology and laminar reduction sequence in the initial Upper Paleolithic from Kara-Bom (Gorny-Altai, Siberia). Quaternary International 259, 33-47.

\section{Resumé}

Čepelky (bladelets) jsou obecně chápány jako charakteristický projev mladopaleolitické technologie. Často jsou dokonce považovány za typické artefakty počáteční fáze mladého paleolitu (EUP). Nicméně se ojediněle na některých lokalitách objevují už v paleolitu středním. Produkce čepelek byla doložena taktéž v iniciálním mladém paleolitu (IUP), jak dokládají např́íklad soubory z lokalit Boker Tachtit (Negevská poušť́, Izrael) a Kara-Bom (Altajská Republika, Ruská Federace). Ve středoevropském bohunicienu (součást IUP technokomplexu) byly dosud popsány pouze izolované nálezy čepelek, ale nedávno objevená a zkoumaná lokalita - Ořechov IV - Kabáty v údolí Bobravy nedaleko Brna - poskytla značný počet (přes 1000 kusů) charakteristických mikročepelek, čepelek a velmi drobných levalloiských hrůtků (spadajících metricky do kategorie čepelek). U tohoto souboru je zcela zřejmý trend v mikrolitizaci, který můžeme chápat jako další vývojové stadium, ale může souviset i se vzdáleností od zdroje suroviny či odlišnou funkcí lokality. Dosud ne zcela vyřešená je otázka datování souboru z Ořechova, který se na základě aktuálně dostupných dat jeví jako mladší v porovnání s klasickými lokalitami Bohunice a Stránská skála. Nové poznatky o bohunicienu v zázemí brněnské kotliny dokládají mnohem vyšší stupeň technologicko-typologické heterogenity bohunického technokomplexu ve střední Evropě, než se dosud myslelo. Nicméně nové poznatky dobře zapadají do pestré mozaiky IUP industrií v Euroasii.

\section{Contacts}

Yuri E. Demidenko

Zakarpats'kij ugors' kij ìnstitut ìmenì Ferenca Rakocì II

ploŝa Košuta 6

UA-90200 Beregovo

$\&$

İnstitut arheologiï NAN Ukraïni

pr. Geroïv Stalìngrada 12

UA-04210 Kiïv

yu.e.demidenko@gmail.com

\section{Petr Škrdla}

Archeologický ústav AV ČR, Brno, v. v. i.

Čechyňská 363/19

CZ-60200 Brno

skrdla@arub.cz

\section{Tereza Rychtaříková}

Archeologický ústav AV ČR, Brno, v. v. i.

Čechyňská 363/19

CZ-60200 Brno

nienna11@gmail.com 
